This item was submitted to Loughborough's Research Repository by the author.

Items in Figshare are protected by copyright, with all rights reserved, unless otherwise indicated.

\title{
Politics, ideology and utopia: a defence of eutopian worlds
}

PLEASE CITE THE PUBLISHED VERSION

http://dx.doi.org/10.1080/13569317.2011.607295

PUBLISHER

(C) Routledge (Taylor \& Francis)

VERSION

AM (Accepted Manuscript)

LICENCE

CC BY-NC-ND 4.0

REPOSITORY RECORD

Kinna, Ruth. 2019. "Politics, Ideology and Utopia: A Defence of Eutopian Worlds". figshare. https://hdl.handle.net/2134/8940. 
This item was submitted to Loughborough's Institutional Repository (https://dspace.lboro.ac.uk/) by the author and is made available under the following Creative Commons Licence conditions.

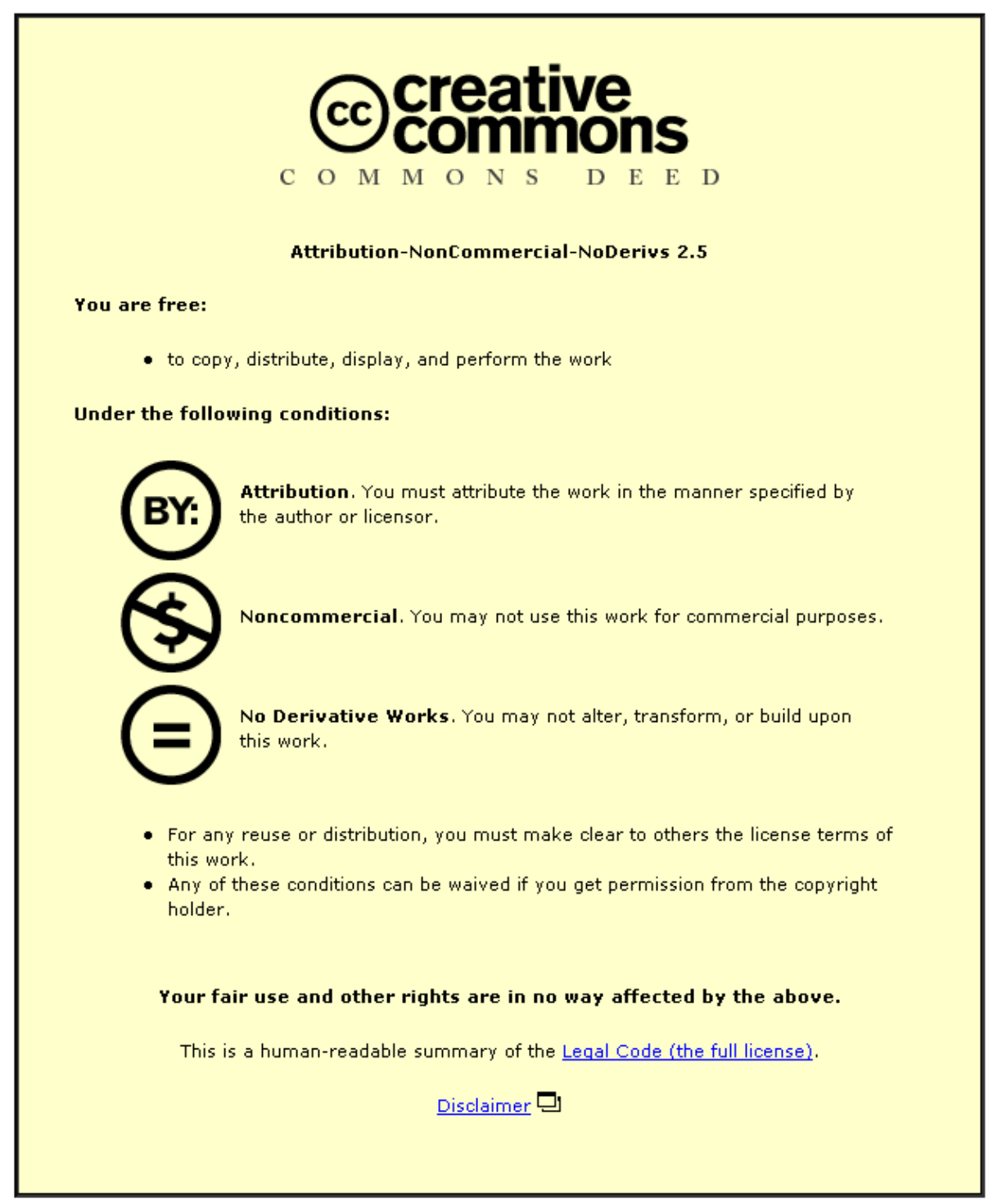

For the full text of this licence, please go to: http://creativecommons.org/licenses/by-nc-nd/2.5/ 


\title{
Politics, ideology and utopia: a defence of eutopian worlds
}

\author{
RUTH KINNA
}

Department of Politics, History and International Relations, Loughborough University, Leicestershire LE11 3TU, UK

ABSTRACT This article examines a recent shift in radical thinking about utopia and a critique of traditional socialist utopianism that has emerged from it. It argues that this new form of utopianism mistakenly treats the idea of future transformation as an illiberal ideological commitment and that it fails to distinguish adequately between different models of socialist utopian thought. The result is a form of utopianism that strips utopia of one of its central elements, the eu-topian aspect. The argument draws on the critique presented by Simon Tormey and a comparative analysis of the socialist utopianism of William Morris-the most celebrated British socialist utopian of the late 19th century-and Ernest Belfort Bax.

\section{Introduction}

It is not unusual to find dramatic shifts in the evaluation of utopian ideas. Writing at the end of the 1950s, Paul Goodman observed how a 'long spell of Marxian "scientific" realism and businessmen's "hard-headed realism" had given way to an enthusiastic embrace of utopianism. ${ }^{1}$ In recent times, a similar shift is detectable. The overtly utopian claim of the alter-globalization movement that 'another world is possible' has inspired another positive re-evaluation of utopianism. These two shifts have apparently little in common. Indeed, the technological, consumptionpatterned ideal that Goodman dubbed 'future-thinking' utopianism is an anathema to contemporary utopians. Its urban, televisual, automotive vision is more likely to be identified as a disastrous feature of the globalized world than an achievement. Nevertheless, they share something in common: for both, the embrace of utopianism is based on a re-appraisal of an older conception. Rather than harking back to the ideas of the early 19th-century utopian socialists or, more proximately, the Marxist anti-utopian utopianism of the late 19th and early 20th centuries, both reject the key features of these earlier traditions.

The question Goodman asked about the utopianism of the 1960s was what it concealed. My question is slightly different: what has been lost in the critique of 
RUTH KINNA

socialist utopianism? My answer, though, is similar to his. Goodman argued that future-thinking utopianism, lacking the "common sense and parsimonious sweetness of Fourier or William Morris', ${ }^{2}$ failed to understand the 'plea for community' that lies at the heart of the socialist tradition. ${ }^{3}$ My argument is that this new form of utopianism tends to read into old-style socialist utopian thinking a set of ideological commitments, which has encouraged a similar neglect. Whilst contemporary utopianism is undoubtedly appealing by comparison to the earlier image of utopia it conjures, its categorization of socialist thinking is too blunt; and the ethical issues that an earlier generation of writers attempted to address, albeit imperfectly, have been sidelined rather than developed. To show this I examine Simon Tormey's conception of ideological utopianism and discuss the utopianism of William Morris - the most celebrated British socialist utopian of the periodand his friend and collaborator, Ernest Belfort Bax.

\section{The critique of socialist utopianism}

The novelty of the alter-globalization movement is often linked to its internal complexity, plurality, rhizomatic behaviours and its ability to serve as an umbrella for a range of alternative groups and cultures. ${ }^{4}$ Its utopianism is similarly complex and fluid, distinguished by commitments to hallmarks or generic principles, rather than manifestos or party pledges, and advanced by multiple groups operating on the horizontal principles of organization, informally networked through transitory, dynamic actions. Anarchism has played a central role in the conceptualization of this brand of utopianism, but the relationship of the 'movement of movements' to the anarchist tradition is not straightforward. In an early analysis of the global justice movement, Barbara Epstein referred to its 'anarchist sensibility' but carefully distinguished this from 'anarchism per se'. ${ }^{5}$ More precisely, Saul Newman identifies the utopianism of the alter-globalization movement with an anarchistic shift from 'scientific utopianism' (identified primarily with Marx but also Bakunin and Kropotkin) towards a 'utopianism of revolt'; the rejection of scientism, rationalism and positivism in favour of spontaneity, rebelliousness and the expression of an unfilled 'shared imaginary'. ${ }^{6}$ In Simon Tormey and Andrew Robinson's work, the distinction is between the old-style leftist anarchist 80 utopianism and the radical utopianism of the post-left anarchy. These labels represent two entirely different approaches to utopian thinking. The first is identified with 'the separation of the present and the future, and the organizational tendency to reshape the world according to a model'. The second overcomes that separation and abandons the secret islands of planned utopia in order 'to realize one's desires immediately, in concrete social actions and relations'. ${ }^{7}$

Tormey's critique of leftist anarchist utopianism points to a broader dissatisfaction with traditional socialist ideologies. His critique identifies both philosophical and political failures in the tradition. The philosophical failures flow from the identification of an essential goal-for example, distribution according to need, classlessness-which serves as the focus for revolutionary struggle and 
transformation. However it is defined, this goal assumes the incorporation of others-variously designated as the oppressed or the workers-in the struggle for its realization. Moreover, it points to a concept of transformation which is unrealistic and self-defeating. Typically, political action is reduced to 'the teleological unfolding, recuperation or construction of an endpoint that is rational and true' ${ }^{8}$ The political failure of traditional utopianism is that it is fundamentally oppressive. In the name of promoting a better way of life, he argues, utopias stifle contestation, creativity and uncertainty in a presumed consensus on shared commitments, harmonious coexistence and the internalization of moral rules. Utopias spell the end of politics 'or the end of the political as a creative act'. In utopia the "creation has already taken place: we already have the image of the world where we want to be, whether we call it "communism", "anarchy", or "capitalism". Creativity exists only for the means not for the end'.

The claim that utopias typically stifle politics is a familiar one. Marie Louise Berneri argued that utopians were characteristically authoritarian, seeking happiness in material well-being and sinking 'individuality into the group'. ${ }^{10}$ Post-war liberal anti-utopians like Isaiah Berlin and Karl Popper voiced similar concerns, linking utopian dreams - expressed particularly strongly in socialist theory - to the dystopian realities of the European socialist experience. However, Tormey locates the problem of utopianism in deferral and argues that assumptions about history's progressive march are only a symptom of this conception. Whatever role utopians assign to history, he argues that it is the idea of rupture that is mistaken. Utopians wrongly "encourage us to think of politics as the construction of a new Tomorrow, a model of social and political rationality necessitating a complete or fundamental break from Today'. ${ }^{11}$ The promise of future happiness justifies sacrifice and is utilitarian and elitist. Those who understand what the future should be have a special capacity to determine both the sacrifices it demands and who should make them. Tormey also points to the problem of modelling or engineering. As Chamsy El-Ojeili notes, he accepts much of the liberal critique of Marxism ${ }^{2}$ but he does 120 not locate the failures of socialist utopianism narrowly in Marx's thought or even socialism. Any conception of the good-stateless or otherwise-is just another form of negative utopianism. Indeed, insofar as liberal anti-utopianism was always linked to a normative project and to a particular idea of the good, Tormey argues that it was itself 'intrinsically utopian'. ${ }^{13}$ Authentically radical utopianism embraces multiplicity. In declaring how we would like to live we must all recognize that our ideals are only individual preferences and that the problem of Q1 utopianism is one of 'the incommensurability of utopias'. ${ }^{14}$ As Tormey notes, in liberal politics, the term is usually linked to antagonism, 'agonism' and contestation. ${ }^{15}$ As it is brought to bear on utopian thinking, however, the concept stretches beyond the embrace of value pluralism or the defence of agonistic liberalism, to the celebration of 'autonomous', 'anti-authoritarian spaces'; 'spaces of imagination and creativity' which are 'contingent, open, negotiated, unpredictable, beyond capture'. ${ }^{16}$ The utopianism he endorses describes a politics

${ }_{\text {Q3 }}^{\text {Q2 }}$ that gives free reign to diversity and seeks to create 'a space in which "all worlds are possible, where all may live the dream"'. The forms that he rejects he calls 
RUTH KINNA

'ideological': imaginary worlds that conjure images of 'new' or 'better' places and/or which operate 'on the basis of a definite axiom or logic of organisation'. ${ }^{17}$ The result is a concept of utopianism which strips utopia of one of its central terms, namely its eu-topian aspect.

140 In re-casting of utopia as a space for radical politics, Tormey does not reject utopia's descriptive element. Nevertheless, his conception is difficult to reconcile with the definition offered by Ruth Levitas - the 'desire for a better way of living expressed in the description of a different kind of society that makes possible that alternative way of life'. ${ }^{18}$ It fits more neatly with descriptions of 145 utopia's disruptive potential. Mannheim's idea of utopia as the incongruity of states of mind with existing realities that pass into actions and shatter the order of things aptly captures its spirit. ${ }^{19}$ However, insofar as it draws together currents of socialist utopian thought that have usually been treated separately, Tormey's critique points to an understanding of socialist utopianism that is novel. ${ }^{20}$ In 150 particular, the association of deferral and rupture with imaginary models and ideas of the good blurs the distinction between the utopian socialism associated with Fourier, Owen and St Simon, who devised detailed blueprints, on the one hand, and Marx's anti-utopian utopianism, on the other. Marx finds a home with them because - notwithstanding his criticisms of the utopians' failure to see the futility

155 of their non-revolutionary approach and his stubborn refusal to elaborate a detailed picture of the future- he cherished an image of a re-shaped world 'after' the revolution.

So defined, it is difficult to see how the gulf between socialist utopianism and the utopianism of the alter-globalization movement might be negotiated. In 160 contrast to both Goodman and Colin Ward, who remained open to the influence of traditional utopianism, especially the work of 19th-century socialists, Tormey is suspicious of this literature. Ward thought Morris a 'wise' utopian. ${ }^{21}$ Tormey describes Morris's 'gift-economy' in News From Nowhere as a variant of essentialist Marxism or anarchism. ${ }^{22}$ What does he miss? My suggestion, based on

165 the discussion of Morris and Bax's thought, is that he places too great an emphasis on the notion of rupture and that he overlooks the very different ways in which socialists of different stripes linked revolutionary transformation to utopian possibility. As a result, he overstates the case for incommensurability and neglects the significance of the organizational frameworks which diverse groups might hope to create in order to live in plurality.

\section{Morris's utopianism}

In his study of English utopias, A. L. Morton categorized News From Nowhere, 175 William Morris' utopian romance, as the first utopia that was not utopian. ${ }^{23}$ By this, he meant that Morris broke new ground by harnessing the idea of utopia to an analysis of socialist struggle. As Morton puts it, he combined 'the imagination of a true poet' with 'scientific method' gleaned from Marx. ${ }^{24}$ Saul Newman's recent discussion of anarchism and utopianism takes a contrary view: Morris was a 180 pioneer, but a precursor of new radical thinking, whose work illustrates the limits 
of socialist utopianism. Grouping him with Landauer and Le Guin, Newman classifies him as a utopian of a particular imagination and contrasts his work with the 'scientific' anarchism of Kropotkin and Bakunin. ${ }^{25}$ The character of Morris's utopianism and the extent to which he drew upon the scientific tropes of late 19thcentury thought is clearly germane to the consideration of his utopianism. On Newman's account, Morris is an exception who proves a rule and a poor choice to discuss socialist utopianism. On Morton's, Morris is useful only insofar as he bucked a trend in scientific socialism by embracing utopian aspirations. As will be argued below, neither claim is quite accurate. Morris' significance as a 190 representative of the utopian socialist tradition rests - as Morton argues_on his engagement with scientific socialism. Yet the novelty of his thought stems from the misgivings he had about the implications of socialist science and his critical, utopian response to widespread expectations about historical development in the late 19th century. This novelty did not lead him to reject notions of rupture, but to think about the moment of revolution and deferment in a distinctive way.

As Morton argues, by the standards of the day Morris's Marxism was in many ways quite orthodox. His insights into capitalism's operation and the goal of socialism dovetail with Marx's, and he absorbed both through his own reading of Capital and the instruction that he took from his friend, the philosopher Ernest Belfort Bax. Morris tied the realization of revolution to a dialectical process of change, assumed that history was the history of class struggles, that capitalism was a progressive stage of development shaped by changes in productive forces and that it was a necessary precursor to socialism. Whilst Morris coupled these theses to a theory of ethical development that was unconventional, this departure did not in itself point to the imaginative approach to utopianism that Newman identifies. The Manifesto of the Socialist League (1885), jointly authored with Bax, summarized his general view. 'Social evolution', he argued, described a 'revolution in ethics' as well as an 'economical' change. ${ }^{26}$

The vision that emerged from this account of change was egalitarian, its

210 structural features shaped by a desire to overcome exploitation and realize the communist principle of distribution according to need. In the Manifesto, Morris also called for the destruction of international boundaries, the introduction of free labour and the abolition of marriage: freedom in reproduction as well as production. The lynchpin for his utopia was the realization of productive leisure through the transformation of labour through art. Assuming that individuals were necessarily productive beings, Morris envisaged a society in which each would develop a range of skills both to produce useful and beautiful things and perform tasks with grace and ease, voluntarily for their own joy, for the love of giving and/or the recognition attached to it. Whilst still formally subject to the "tyranny of nature', individuals would no longer feel tyrannized by the necessity to labour and would thus be free to shape the world according to their creative desires. ${ }^{27}$

Morris described the ethic of communism as 'brotherhood' or, more usually, 'fellowship'. In general, this concept expressed an idea of solidarity among strangers or, as Bax puts it, "“one for all and all for one," the spirit of common interest, of mutual standing with one another as a body, quite irrespective of 


\section{RUTH KINNA}

individual likes or dislikes' ${ }^{28}$ More richly he linked fellowship to a set of social relationships which arose from the direct experience of oppression. These relationships were inter-generational and they were sustained by ideas of hope, loyalty, mutual support and individual sacrifice. Presenting a Christianized version 230 of the idea in The Dream of John Ball, Morris intimated that the perfect demonstration of fellowship was the willingness to die a martyr's death. As a supreme expression of commitment, martyrdom memorialized earlier struggles, providing continuity for future action. Morris's view- 'though I die and end, yet mankind yet liveth, therefore I end not, since I am a man'-is inspired by John Ball's belief that to die is only to live 'in some new way'.29

Morris's utopianism exhibits many of the features of traditional socialist thinking. His communist utopia is cast into the future; it clearly represents a break with the old world and its realization makes a virtue of deferred benefit, motivating individual sacrifice. Yet the way in which Morris cemented his ideas together 240 suggests that the relationship between deferral or rupture and ideological determination is not as straightforward as Tormey assumes. Morris argued that there was a disjuncture between the process of historical change and the utopian goal. As Morton rightly argues, his utopia was informed by the insights of scientific socialism, but the realization of his vision depended on the negation of the future it 245 presaged rather than its fulfilment, leaving a space that could not be filled by incorporation. Morris sought to fill the gap between reality and utopia by building into the present a commitment to transformation that was motivated by an aspiration to live differently. His treatment of the relationship between the process of change and the goal of communism not only represented a striking departure

250 from orthodoxy; it also opened up a division between his position and the already unorthodox Marxism of Bax. At the heart of the divergence were two different accounts of ethical change.

Morris's understanding of ethical transformation was restorative: in looking forward to the future he hoped to rekindle a set of behaviours which commercial competition had destroyed. In The Dream of John Ball he identified these lost behaviours with artisans of the 1381 Peasant's Revolt, and he captured their quality by contrasting the peasants' moral courage with the vacillation of 19thcentury workers. These two groups were victim to different forms of oppression, but Morris argued that they could nevertheless be characterized in the same broad terms: their cause was to be free from 'mastership' and 'fleecing'. The significant difference between them lies in their response to oppression. Whereas the artisans faced their oppressors with brave determination, 19th-century workers were typically sluggards: doltish and cowardly, they had been seduced by the incentive systems on which capitalist relations were based. As Morris told John Ball, the 265 workers had been 'blinded to the robbing of themselves by others, because they shall hope in their souls that they may each live to rob others' ${ }^{30}$ The irony of the situation was that these workers stood at a point of revolutionary transformation and had a real opportunity to deliver themselves from exploitation and oppression. The artisans' struggle was never likely to have succeeded, for all their 270 commitment and courage, because historical forces had been stacked against 
them. In the earlier period, the impending social rupture played in capitalism's favour. Morris found the proof in tracing the long-term results of the revolt: the artisans were released from feudal obligation only to endure the hardships associated with the market freedom of wage slavery.

The lesson that Morris took from history was that the success of the 19thcentury revolution hinged on the expression of fellowship, the social force that had impelled the peasants to relocate mastership in order to confront the historical forces ranged against them. Arguing that its loss could be recouped and that it was possible to encourage 19th-century workers to see beyond capitalism's seductive barrier, he embarked on the policy of 'making socialists', writing the story of the Revolt as a small contribution to this educative project. In the story itself, he also described his hope, reassuring John Ball that the 'time shall come, when that dream of thine ... shall be a thing that men shall talk of soberly, and as a thing soon to come about'. Men 'shall be determined to be free' and 'the Fellowship of Q3 Men shall endure, however many tribulations it may have to wear through'.31

Bax's understanding of ethics was innovative. ${ }^{32}$ He charted the process of historical development by mapping three models of social relations to three parallel forms of consciousness: first, 'primitive' or 'natural' communism and pagan-classical thought; second, individualism and early Christianity and Protestantism; and third, future communism and the religion of socialism. Believing that history followed a dialectical path in which material and ethical changes interacted in a continuous movement, this sociological model enabled Bax to make some general projections about the character of socialism. As the transcendence of primitive communism and individualism, socialism would bear the primary characteristics of primitive communism-duty and solidarity-but in a manner mediated by the history of individualism. So whereas primitive communism had been limited by ties of blood or kinship, the religion of socialism would support a global, generalized duty based on the recognition of the equality of peoples. ${ }^{33}$ Bax denied that the progression he mapped followed a path defined 300 by reason. Departing from Hegel, whose idealism he generally embraced, he instead followed Schopenhauer to argue that reason was itself animated by the alogical principle associated with passion, feeling and sentiment. Nor did he envisage the future as an improved version of the present. Reflecting on the qualitative changes socialism would bring, he anticipated that the movement 305 leading to socialism would re-balance ethical with material forces and bring a new set of relationships to the fore. The struggle for subsistence had hitherto given general primacy to material forces, but in socialism - the realm of freedomethical forces would for the first time become primary motors of change. This meant that the mind would be freer than ever before to determine the conditions of social existence.

For both Morris and Bax socialism was in some respects indeterminate. In Morris's account, the indeterminacy described an uncertainty about the commitment of ordinary people to fight slavery, reclaim mastership from elites and realize a genuine alternative to capitalist practices and state organization through the transformation of labour into art. Capitalism was poised to collapse 
RUTH KINNA

but there was a strong possibility that the opportunities to bring the system to an end would not be seized. For Bax, the process of change was certain, but there was considerable space for individuals of a particular passion to hasten the process of change. Moreover, whilst reason indicated the direction of historical development, the form that socialism might take was unclear.

Viewed through Tormey's critical lens, both Morris and Bax used their understanding of history to generate a utopian vision. Yet their account of ethics led them in very different directions. Morris scholars argue about the extent to which the vision he described in News From Nowhere should be read impressionistically or taken as a literal picture of the future, but however it is interpreted, there is little doubt that he consciously encouraged readers to reflect on Nowhere's goodness. As Ruth Levitas puts it, Nowhere is 'an imagined alternative future which serves to transform the present'. ${ }^{34}$ It was essential to think creatively and imaginatively about the future, because in the absence of an inspirational alternative, present trends would merely continue unchallenged. Moreover, there would be no way of assessing the worth of competing claims about how to organize in the here and now and whether or not to enter into fellowship with others engaged in similar everyday struggles. Though Morris disliked it intensely, Edward Bellamy's Looking Backward had been enlightening in this respect. Was his picture of

335 'extreme ... national centralization' or 'State Communism' worth fighting for? ${ }^{35}$ Bellamy presented it under the banner of socialism, but Morris did not think so. He acknowledged that his utopia was as idiosyncratic as Bellamy's, an expression of his own temperament and a reflection of his particular desires. The book was 'egoistical', he said. ${ }^{36}$ Yet, the fact that it captured a 'private dream' did not mean

340 that it might not resonate more widely. By his own reckoning he was not 'so utterly different' from other people; a composite of at least 'a dozen persons'. The facets of his complex personality were 'but types of many others in the world' 37 He was not surprised, then, to discover that 'a good many people' (ultimately, not enough) found his 'aspirations pleasant'. ${ }^{38}$ By presenting the description of 345 Nowhere as a friend's description of a comrade's dream, Morris even structured the correspondence of hope into the narrative. As the bearer of the comrade's testimony, the friend relates the dream in the first person, emphasizing the identity of their desires. By this device Morris established a line of transmission which lends the dream a prophetic quality. At the end of the book he invites readers to consider its relationship with their own aspirations, and his suggestion that they have the power to transform the dream into a vision endows Nowhere with the force of revelation.

Unlike Morris's vision, Bax's could only be seen in the mind's eye. He not only denied that the picture of socialism was integral to the process of transformation, but he also thought it irrelevant. All that mattered was the insight into the process of change and the ability to act upon it. Indeed, any suggestion that the future could be imagined was preposterous. Though he thought that there was some purpose in making policy in advance of the revolution, he characterized 'Utopian socialist writings' as mere travesties 'of the society of the present, or of the past'. It 360 was possible to 'define, that is, lay down, in the abstract, the general principles on 
which the society of the future will be based, but we cannot describe, that is, picture, in the concrete, any state of society of which the world has had no Q4 experience'. 39 History has taught that the future would expand th realm of freedom, but Bax argued that it was impossible to tell how this freedom might translate into everyday practices or ways of living. Indeed, whereas Morris was willing to describe the organization of socialism by abstracting from history and reflecting on the conditions for art's rebirth, he argued that historical change made the past itself impossible to grasp, Bax's contention that the alogical was something that reason could not properly grasp, led him to the conclusion that individuals were always trapped by the limits of current understanding. Although it was possible to identify retrospectively patterns of historical change and use these to predict the likely shape of the future, the past could not help fill out the details of the future because both were inevitably mere projections of the present. Bax's fantastic and tantalizing conclusion was that whilst the mind was poised to discover a new kind of freedom, the nature of this freedom was utterly unimaginable.

The divergent character of Morris and Bax's utopianism reflected their equally different ideas about the relationship between the present and the future. Of the two, Bax alone understood the future as a process of unfolding. For Morris, socialism described a better place but one that was contingent on action in the present. As a result, whilst Bax was drawn towards utilitarianism, Morris was not. On the question of socialist transformation, Morris' suggestion that it was possible to find ethical continuity between communism and pre-capitalist society indicated there was a qualitative difference between the present and the future, but also a 385 relationship between the two. Only the full flowering of communism would facilitate the transformation of work into art. On this account, the revolution did not mark the sudden death of corrupt practices and the immediate birth of newly restored moral behaviours. Fellowship, the ethic of socialism, was the central ingredient in the struggle for socialism. Bax's view, that individuals would be 390 swept along by the alogic of history into a new set of social relations, found a parallel in Morris' work, but fellowship described conscious commitment, not a developing consciousness. And although he adopted a fairly standard view of what the revolution entailed, the expression of an abstract ideal and the incorporation of the others as vehicles for social transformation were not-as they were for Baxpart of the package.

As Tormey suggests, by setting socialism into an imaginary future, Morris was led to believe that the struggle for utopia involved an emotional commitment to others, that it might well result in martyrdom and that it typically involved sacrifice. His pessimism about the possibility of securing meaningful change in the body of capitalism also led him to associate revolutionary action with negative behaviours and risk, rather than the creative development of challenging alternatives. Having given up the possibility of living such an alternative in the company of his fellow artists for the sake of fighting for capitalism's general destruction, he had concluded that it was impossible to hasten the structural transformation necessary for the universal enjoyment of art from the privileged 


\section{RUTH KINNA}

space that he occupied. His gamble was that he would lose both art as well as the revolution, because capitalism did indeed provide him with a space to do what he wanted, albeit on terms he did not like. Yet here, too, there was an important difference with Bax. Morris's strategy was to demonstrate the superiority of socialism in the hope that it might help inspire a similar desire for revolutionary change in others. Issuing his appeals to ordinary people, he exemplified the mundane acts of other, equally ordinary individuals. His response to the death of Alfred Linnell is a good illustration of his approach. Linnell had been involved in an anti-unemployment demonstration at the Trafalgar Square on 20 November 1887, and died after sustaining an injury inflicted by the police. Unlike John Ball, Linnell had expected to return home after the demonstration, but this was irrelevant to Morris's estimation of the value of his sacrifice. Linnell was everyman, significant precisely because he was not extraordinary, and although his presence was less spectacular than, say, an intervention to shield a fellow demonstrator from harm or arrest, his death symbolized a living commitment to fellowship. At the funeral Morris implored the mourners: 'Let us feel he is our Q5 brother. ${ }^{40}$ His speech at Linnell's funeral was reported in the press:

There lay a man of no particular party - a man who until a week or two ago was perfectly obscure, and probably was only known to a few .... Their brother lay there-let them remember for all time this man as their brother and their friend .... Their friend who lay there had had a hard life and met with a hard death; and if society had been differently constituted from what it was, that man's life might have been a delightful, a beautiful one, and a happy one to him. It was their business to try and make this earth a very beautiful and happy place. $^{41}$

Possessing a keen sense of 'the chant of the goblins of destiny', ${ }^{42}$ Bax in contrast reserved a special role for those who understood the beating heart of history. He even knuckled down to the prospect that 'the energetic minority' would in all probability have to act 'in opposition to ... the inert mass', ${ }^{43}$ nominating the 'European Socialist party' as the 'authoritative tribunal' on the grounds that they had the 'real welfare' of the 'count-of-heads majority' at heart. ${ }^{44}$

In sum: Morris' differences with Bax point to two different logics which Tormey's critique fails to acknowledge. In Morris' thought the realization of Q6 utopia is contained within the dynamic of struggle. Although there was a significant difference between his view and, say, Fourier's (namely that he could no more tolerate the idea of utopia as an oasis in the body of capitalism than Marx), like the utopians of the early 19th century, he relied on voluntary subscription, not incorporation: the prospects for utopia rest on the engagement of ordinary people. In Bax's work, by contrast, the process of change is transcendent. Socialism lies in the future but its achievement is part of a process of dialectical change, necessitating judgements about policies for its advancement. There is a clear understanding that those best equipped to interpret social development and conceptualize the collective benefit which the future will bring should determine 450 revolutionary policy. 


\section{The problems and possibilities of socialist eutopias}

If the rupture Morris imagined did not lead him to commit the same strategic errors as Bax, his utopianism undoubtedly fails the test of incommensurability. The vision of Nowhere is a particular idea of socialism, where the privilege that Morris had to 'play' and avoid 'work' — as he put it in The Dream of John Ball—was enjoyed in common. ${ }^{45}$ It necessarily restricts the possible set of utopias that might be contained within it. In addition, because Morris considered the production of art a social act; critics have objected that it anticipates a harmonization of interests that is both unrealistic and undesirable. ${ }^{46}$ Before turning to consider the formal constraints of his utopia, it is worth considering this critique and Morris' conception of politics.

Morris was happy to describe Nowhere as a place without politics and by this he meant not only that it had abandoned representative parliamentary institutions, but that disagreements manufactured by sectarian interest would disappear. His conception of politics chimed in with much 19th-century socialist thinking and it was informed by a broad distrust ingrained in the artistic circles he inhabited: the shock felt by his friends on hearing his decision to give up art for socialism reverberated not from the radicalism of his position, but his immersion in a world linked with grubby deals and the compromise of principle. In these circles politics was a dirty word, associated with hypocrisy, duplicity and self-seekingeverything that art and poetry were not. Louisa Bevington's description of the 'public muddle' and 'private scramble' of 'Lunatic Land' and the peace and liberty of 'Common-sense Country' where 'prophets, or poets' thrived, aptly captured this view. ${ }^{47}$ Like her, Morris also understood politics as the antonym for art: ugliness and, above all, pretence. Importing this idea into his socialism, he concluded that removal of economic power advantages and the recovery of mastership would release individuals from the grip of these vices. As he explains in Nowhere, class politics never offered a route for the articulation of genuinely or deeply held opinions; it operated to conceal the actual coincidence of elite interests and as a cover for oppression. How else, Morris asked, could elites have 'dealt together in the ordinary business of life ... eaten together, brought and sold together, gambled together, cheated on other people together'? ${ }^{48}$ With the abolition of elite politics, the theatricality of performance would open the way for a new craft of honest exchange: popular creative expression through social engagement.

The hypocrisy Morris identified in bourgeois politics corresponds with what Tormey calls the rhetoric of liberalism: the freedom to contest everything except "the "freedom" of the free market, the rationality of representation, the monopolising nature of anti-monopoly legislation, the tyranny of "choice". 49 Nevertheless, the diversity he imagines in Nowhere does not have the diffuse, permanently creative quality that Tormey looks for. Instead, Morris points to the diversity of language and culture and comments on the variety that springs from popular art. ${ }^{50}$ There are disagreements and even room for discontent. Violent disputes - between men rather than against women-spring from jealous rivalry 


\section{RUTH KINNA}

and romantic disappointment. Despite the achievement of gender equality, in Nowhere men still fight for the love of women and women continue to meddle with their emotions. This divergence is managed by the principles of interaction which have freed women from the restrictions of bourgeois law, but Morris supposed that these tensions could never be eradicated. Yet life is convivial and for all the diversity and occasional conflict, Morris downplayed the significance of contestation.

Rather than being defined by experimentation, the art of utopia is based on creative refinement. Just as the inhabitants of Nowhere learn how to perfect 505 design techniques over time, matching functionality with style and polish, they also become adept in dealing with public disputes. As Laurence Davis has rightly argued, the perfectibility of utopian politics in part reflected Morris' oversimplification of the 'institutional sources of social conflict'. 1 Perhaps optimistically, he assumed that the abolition of capitalist markets and private 510 ownership of the means of production would overcome fundamental disputes about 'the build of the universe and the progress of time' ${ }^{52}$ In the other part, however, the quality of utopian politics was explained by the sophistication of political skills that the inhabitants of Nowhere acquired. The ethic of socialismfellowship_played an important role here, facilitating the development of

515 consensus decision-making. Although individuals disagree about 'real solid things', these disagreements do not 'crystallise people into parties permanently hostile to one another'. ${ }^{53}$ Admittedly, in critiques of anarchism towards the end of his life, Morris adopted a more strongly republican position which rooted resolution in the identification of common interest, but in his more libertarian

520 phases he assumed that differences were reconcilable through open, equal, reflective and direct discussion of the bodies concerned. Bourgeois politics suggested that politics was about conflict. In Morris's view, this was misleading. He believed that it was possible to secure consensus through mutual respect and a wish to find agreement, and he treated resolution as a social goal. In doing so, he adopted a conception of politics clearly at odds with the post-left utopianism Tormey supports.

The formal restrictions Morris introduced in communism placed a further barrier between his idea of utopia and the anti-eutopian concept. Tormey recommends indifference about the organization of utopian spaces. They are offered 'without constraints, obligations, contracts, permanently binding rational or "universal" features'. 54 In contrast, Morris sought to impose an absolute prohibition against 'slavery'. In utopia it was not permissible for any group or individual to institutionalize exploitation or oppression. Morris imagined that all members of his future federation would commit themselves to this rule, no matter 535 how they decided to organize themselves locally. But in the event of deviation he allowed that breaches could be resisted with force. In addition, Morris admitted that fellowship would function as a form of social conditioning. He recognized that some socialists might find this idea troubling and his response was that it was impossible to abolish 'the tyranny of society': the idea, which he associated with 540 anarchism, 'that every man should be quite independent of every other' was, he 
said, ridiculous. ${ }^{55}$ Individuals could live more or less isolated lives, but their social conditions would always impose constraints. Yet, just as it was possible to transform the 'tyranny of nature' by turning work into play, it was also possible to uncouple this background 'tyranny' from the legal tyranny which prevailed in statist societies. By providing a secure ground for fellowship, Morris perhaps imagined that communism would shape utopia in the same way that bourgeois rule and market relations conditioned social life in capitalism-and with similar complexity. In seeking to change the terms of association he certainly hoped that the informal regulation of society would overcome the need to enforce the formal prohibitions on exploitation and oppression that were essential to utopia's existence.

To summarize, in utopia different groups and individuals live well together, expressing their particular interests and differences, because they have taken an active role in shaping this ideal. Nowhere is not filled with phalansteries or closed small-town communities; it leaves space for movement, wandering and personal adventure. It assumes a common commitment to an idea of social life that is defined by resistance to slavery. Insofar as everyday politics was concerned, Morris imagined a future in which agreement was the norm. His anticipation of the dovetailing of desire and his faith in fellowship, epitomized in Nowhere by the friendliness of strangers, led him to believe that disparate individuals would all be able to feel at home in socialism and work out their differences amicably. This embrace of consensus is a significant marker of Morris's utopianism. The question is: does this provide a reason for rejecting wholesale the idea of a utopian world?

Tormey's criticism of socialist utopianism is that it wrongly subordinates politics to ideology and assumes the incorporation of others in apocalyptic struggles for future worlds that are illusory and self-defeating. Morris's utopianism suggests that some of the arguments on which this critique is based are mistaken. As Buber argued, to hold an ideal of a future world does not necessarily entail the adoption of a utilitarian or hierarchical idea of transformation. Similarly, the attempt to define the parameters of utopia does not require a rejection of politics in the name of ideological conformity. The consensual politics Morris imagined failed to consider how forms of oppression might escape public acknowledgement and how slavery might be defined. In the society of art, it was still possible for everyday practices to constrain or repress individual desires and for individuals to find their behaviours out of step with prevailing currents. Yet this problem remains even where experimentation is preferred to refinement as a model for social engagement. Morris's utopia emerged from an attempt to imagine the least tyrannous condition: the condition that he believed allowed the greatest scope for individuals to determine the patterns of their own lives. However, imperfectly, it recognized the space for politics within an ideological frame.

Although indifferent about their organization, Tormey is concerned about the quality of the spaces within which politics takes place. The test of incommensurability is that the exact specification of how matters are to be organized is to be left to 'individuals and the groups and collectivities that the individual chooses to interact with' ${ }^{56}$ But not all spaces pass this test: liberal utopias are a case in point. 


\section{RUTH KINNA}

Nozick's otherwise instructive analysis of incommensurability is deemed inadequate because he situates the spatial utopia in a "capitalist laissez-faire world of precisely the kind that the movement for global justice ... seeks to displace'. 57 Yet Morris falls foul of incommensurability precisely because he 590 attempted to outline an alternative organizational principle and tried to imagine how diverse groups and individuals might use the spaces it supported creatively. His vision was in some respects naïve and it left important questions about the possibility of consensus and the resolution of difference unanswered. However, these shortcomings might be addressed from within the utopian tradition. There are

595 resonances of Morris's approach to utopia-and his concern with labour-in Nowtopianism, for example. The Nowtopian commitment to immediate practical action and the transformation of life in the present offers more scope for action than Morris thought realistic, but the vision of a world free of 'productive labor' and the belief that nowtopian behaviours will not, by themselves, achieve this revolutionary 600 change supports his utopianism. ${ }^{58}$ Paul Goodman's revisions of the older socialist traditions forged a similar link between the present and the future. His judgement that '[a]ll human societies are patterns of culture' echoes Morris, as does his recognition that patterning does not assume an absence of conflict. ${ }^{59}$ Offering a different conception of politics, he argued that 'conflict is not an obstacle to 605 community but a golden opportunity'.60 However, in his willingness to jettison 'warmth and security' for social invention and 'new character-types', Goodman did not throw out utopia but asked instead how models might be adapted and applied in everyday life. With his feet planted firmly in the anarchist-socialist tradition, Ward similarly conceptualized utopia as 'a million private dreams' - the

610 multiplicity of individual desires each encapsulating a desire 'to do my own thing in my own way'. ${ }^{61}$ Seeing little more than vanguardism and tyrannical conformity in utopia, the anti-eutopian critique Tormey presents misses these possibilities and throws out a potent element in the socialist tradition.

\section{Acknowledgements}

A version of this paper was presented at the Goldsmiths, University of London RUPE seminar. I would like to thank participants for feedback and Laurence Davis, Ian Fraser and Alex Prichard for their helpful comments on earlier drafts of the revised paper.

\section{Notes and References}

1. P. Goodman, Utopian Essays and Practical Proposals (New York: Vintage Books, 1962), p. 3.

2. Goodman, ibid., p. 4.

3. Goodman, ibid., p. 9.

4. G. Chesters and I. Welsh, 'Complexity and social movement: process and emergence in planetary action systems', Theory, Culture and Society, 22 (2005), pp. 187-211.

5. B. Epstein, 'Anarchism and the alter-globalization movement', Monthly Review, 53(4) (2001), available at http://www.monthlyreview.org/0901epstein.htm (accessed 1 November 2010). 
6. S. Newman, 'Anarchism, utopianism and the politics of emancipation', in L. Davis and R. Kinna (Eds) Anarchism and Utopianism (Manchester: Manchester University Press, 2009), p. 207.

7. A. Robinson and S. Tormey, 'Utopias without transcendence? Post-left anarchy, immediacy and utopian energy', in P. Hayden and C. el-Ojeili (Eds) Globalization and Utopia: Critical Essays (London: Palgrave Macmillan, 2009), p. 161.

8. S. Tormey, 'From utopian worlds to utopian spaces', Ephemera, 5 (2005), p. 399.

9. Tormey, ibid.

10. M. Berneri, Journey Through Utopia (London: Freedom Press, 1982), p. 2.

11. Tormey, op. cit., Ref. 8, p. 400.

12. C. el-Ojeili, 'Two post-Marxisms: beyond post-socialism?', in Hayden and el-Ojeili, op. cit., Ref. 7, pp. 4243.

13. Tormey, op. cit., Ref. 8, p. 399.

14. Tormey, ibid., pp. 397, 402.

15. Berlin's critique of the ethical monism of utopianism is discussed by L. Davis in 'Isaiah Berlin, William Morris and the politics of utopia', in B. Goodwin (Ed.) The Philosophy of Utopia (London/Portland, OR: Frank Cass, 2001), pp. 56-86.

16. Tormey, op. cit., Ref. 8, p. 402.

17. Tormey, ibid., p. 395.

18. R. Levitas, 'The future of thinking about the future', in J. Bird, B. Curtis, T. Putnam, G. Robertson and L. Tickner (Eds) Mapping the Futures: Local Cultures, Global Change (London/New York: Routledge, 1995), pp. 257-266.

19. K. Mannheim, Ideology and Utopia: An Introduction to the Sociology of Knowledge (London: Routledge \& Kegan Paul, 1979), p. 173.

20. For a discussion see D. Leopold, 'The structure of Marx and Engels' considered account of utopian socialism', History of Political Thought, 26(3) (2005), pp. 443-466; D. Leopold, 'Socialism and (the rejection of) utopia', Journal of Political Ideologies, 12 (2007), pp. 219-237.

21. Colin Ward, Utopia (Harmondsworth: Penguin, 1974), p. 108.

22. Tormey, op. cit., Ref. 8, p. 399.

23. A. L. Morton, The English Utopia (London: Lawrence \& Wishart, 1978), p. 213.

24. A. L. Morton, Three Works by William Morris (London: Lawrence \& Wishart, 1986), p. 30.

Q8 25. Newman, op. cit., Ref. 6, p. 207.

26. W. Morris and E. B. Bax, Manifesto of the Socialist League (London, 1885), note E, available at http://www. marxists.org/archive/morris/works/1885/manifst2.htm (accessed 25 June 2010).

27. W. Morris, 'Useful work versus useless toil', Signs of Change (Bristol: Thoemmes Press, 1994), p. 107.

28. E. B. Bax, Problems of Mind and Morals (London: Grant Richards, 1912), Ch. 6, note 2, available at http:// www.marxists.org/archive/bax/1912/probs/06-fundament.htm (accessed 25 June 2010).

Q9 29. W. Morris, 'The dream of John Ball', in Morton, op. cit., Ref. 24, p. 89.

30. Morris, ibid., p. 24.

31. Morris, ibid., p. 110.

32. For a discussion see R. Kinna, 'Time, history and utopia', Journal of William Morris Studies, XVIII(4) (2010), pp. 36-47.

33. E. B. Bax, The Ethics of Socialism (London: Swan Sonnenschein, n.d.), p. 21.

Q11 34. Levitas, op. cit., Ref. 18, p. 259.

35. W. Morris, 'Looking backward', in N. Salmon (Ed.) Political Writings: Contributions to Justice and Commonweal 1883-1890 (Bristol: Thoemmes Press, 1994), p. 422.

36. W. Morris, 'How shall we live then?', in P. Meier (Ed.) 'An unpublished lecture of William Morris', International Review of Social History, 16 (1971), p. 223.

37. Morris, ibid., p. 223.

Q12 University Press, 1996), p. 310.

39. E. B. Bax, Outlooks From the New Standpoint, Preface, para. 3, available at http://www.marxists.org/ archive/bax/1891/outlooks/00-preface.htm (accessed 25 June 2010).

40. F. McCarthy, William Morris A Life For Our Time (London: Faber \& Faber, 1994), p. 573.

41. E. P. Thompson, William Morris, Romantic to Revolutionary, 2nd edn (New York: Pantheon Books, 1976), p. 494.

42. E. B. Bax, The Religion of Socialism (London: Swan Sonnenschein, Lowrey \& Co., n.d.), p. 82.

Q13 43. Bax, op. cit., Ref. 33, p. 128.

44. Bax, ibid., p. 122.

45. Morris, op. cit., Ref. 29, p. 113. 


\section{RUTH KINNA}

Q14 46. For a discussion see Davis, op. cit., Ref. 15.

47. L. S. Bevington, Common-sense Country (London: Liberty Press, 1890), p. 11, available at http://www. indiana.edu/ letrs/vwwp/bevington/common.html (accessed 25 June 2010). I am grateful to Ingrid Hanson for directing me to Bevington's pamphlet.

48. W. Morris, 'News from nowhere', in Morton, op. cit., Ref. 24, p. 269.

49. Tormey, op. cit., Ref. 8, p. 400.

Q15 50. Morris, op. cit., Ref. 48, pp. 268-270.

51. L. Davis, 'Isaiah Berlin', op. cit., Ref. 15, p. 66. Davis adopts a more critical stance and finds Morris guilty of adopting an illusory ideal of ethical consensus.

Q16 52. Morris, op. cit., Ref. 48, p. 269.

53. Morris, ibid., p. 269.

54. Tormey, op. cit., Ref. 8, p. 403.

55. Morris, op. cit., Ref. 48, p. 272.

56. Tormey, op. cit., Ref. 8, p. 397.

57. Tormey, ibid., p. 397.

58. C. Carlsson and F. Manning, 'Nowtopia: strategic Exodus?', Antipode, 42(4) (2010), p. 950.

Q17 59. Goodman, op. cit., Ref. 1, p. 8.

60. Goodman, ibid., p. 21.

Q18 61. Ward, op. cit., Ref. 21, p. 5. 